\title{
Cost estimation and planning for HIV/AIDS oral healthcare services: a Malaysian experiment
}

\author{
Chen-Chen Yong $^{1 *}$, Jacob John², Evangelos Koutronas ${ }^{1}$, Thomas George Kallarakkal ${ }^{2}$ \\ From First International Science Symposium on HIV and Infectious Diseases (HIV SCIENCE 2012) \\ Chennai, India. 20-22 January 2012
}

\section{Background}

Reuters reported that $8400 \mathrm{HIV}$ cases were detected in the voluntary screening of drug addicts in Harm Reduction Programmes, and screening in prison and Narcotics Rehabilitation Centers in 2011. However, dental treatment for HIV inmates is highly constrained by high uncertainty resulting from the changes of epidemic profile after receiving medical treatment, relative inadequacy of dental treatment and rules and regulations. Thus institutional HIV dental care cost could pose challenges to government healthcare expenditure.

\section{Methods}

The marginal cost for dental treatment is estimated based on the case scenario of prison X in Malaysia. Based on literature review and economic reasoning, an integrated cost planning model is formed to address the current needs in cost planning.

\section{Results}

The marginal cost for prison dental treatment is estimated to increase by at least 3 folds for prevalence cases and by at least 7 folds for surveillance case in short run. The cost pyramid is formed with the base of cost-consequences, cost efficiency and cost effectiveness planning followed by cost benefit and financial risk planning at the second layer, and cost utility planning at the peak layer. All cost planning components are integrated vertically and horizontally.

\section{Conclusion}

HIV dental care costs for inmates will be at the expense of government revenue if the increased marginal cost is

\footnotetext{
* Correspondence: ccyong@um.edu.my

${ }^{1}$ Faculty of Economics and Administration, University of Malaya, Kuala Lumpur, Malaysia

Full list of author information is available at the end of the article
}

above the average cost. Therefore, cost estimation coupled with the integrated cost planning model is essential for evaluation, monitoring and budget allocation enhancement.

\section{Author details}

${ }^{1}$ Faculty of Economics and Administration, University of Malaya, Kuala Lumpur, Malaysia. ${ }^{2}$ Faculty of Dentistry, University of Malaya, Kuala Lumpur, Malaysia.

Published: 4 May 2012

doi:10.1186/1471-2334-12-S1-P93

Cite this article as: Yong et al.: Cost estimation and planning for HIV/ AIDS oral healthcare services: a Malaysian experiment. BMC Infectious Diseases 2012 12(Suppl 1):P93.
Submit your next manuscript to BioMed Central and take full advantage of:

- Convenient online submission

- Thorough peer review

- No space constraints or color figure charges

- Immediate publication on acceptance

- Inclusion in PubMed, CAS, Scopus and Google Scholar

- Research which is freely available for redistribution

Submit your manuscript at www.biomedcentral.com/submit
C Biomed Central

\section{Biomed Central}

